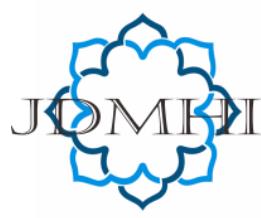

email: jdmhi@walisongo.ac.id

Journal of Digital Marketing and Halal Industry

ISSN: 2716-4810 (print) ISSN: 2716-4802 (online)

\title{
Restructuring MSME Businesses Through the Use of Digital Marketing as a Reflection on the Economic Impact of the Covid 19 Pandemic
}

\section{Rabi'atul Adawiyah', Fajar Adhitya²}

1,2 Faculty of Islamic Economics and Business, UIN Walisongo Semarang

A R T I C LE I N F O

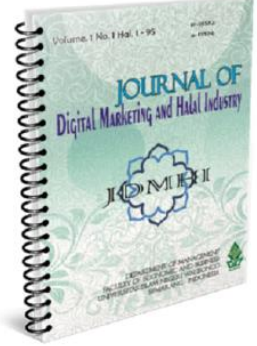

Article history:

Received 27 June 2021

Accepted 15 September 2021

Published 30 October 2021

Keywords:

Price, Product Quality, Product

Design, Brand Image, Purchase

Decision
A B S T R A C T

Micro, small and medium enterprises (MSMEs) are most affected by the Covid-19 pandemic. Therefore, the role of MSMEs is very strategic as it reduces unemployment and poverty in Indonesia, thus providing solutions to economic and social problems. This study analyzes efforts in rescuing MSMEs to maintain the stability of the national financial system affected by the Covid-19 pandemic. The study uses a qualitative descriptive approach with literature review and interviews. The interview's outcome was conducted to 100 MSMEs in Semarang City, Demak Regency and Kendal District shows the issues faced by MSMEs due to the Covid-19 pandemic are decreased sales and difficulty obtaining raw materials, business capitals and paying premises rents, also production and distribution disruption. The study concluded seven strategies for maintaining and increasing MSME sales: transforming its marketing and sales online, diverting products/services line, reallocation of the fund, hygiene, and halal assurance, providing vouchers or gift cards, accelerating asset sales, and reduction of labor. These seven scenarios are expected to encourage MSMEs to improve and develop their capacities to play the role of economic safety nets. However, the results of this study have limitations for MSMEs in areas that are still limited by internet networks, so that they have difficulty implementing digital-based marketing strategies.

@2021 Journal of Digital Marketing and Halal Industry

declared a global pandemic by the World

\section{Introduction}

The world faced significant challenges in 2020 when the Coronavirus (Covid-19) was
Health Organization on March 11, 2020. This declaration was made more than two months after the first case of the Coronavirus. The emergence of Covid-19

\footnotetext{
* Corresponding author.email: rabiatuladawiyah@walisongo.ac.id
} DOI: http://dx.doi.org/10.21580/jdmhi.2021.3.2.8440 
patients was reported in Wuhan City, China, on December 31, 2019. Drastic changes and strategic steps to overcome this pandemic must have affected all aspects of life globally, as it was reported that Covid-19 has spread to 213 countries and regions. In addition to the health sector, the Covid-19 pandemic has also significantly impacted the economic, industrial, tourism, transportation, food, educational, social, and religious sectors.

The United Nations (United Nations, 2020) estimates that economically, the Covid-19 pandemic will have an impact on decreasing global income by up to US\$ 2 trillion. Furthermore, the United Nations Department of Economic and Social Affairs (UN-DESA) in a press release issued by the UN Department of Global Communications (2020) On April 1, 2020, it is predicted that the global economy will shrink by 1 percent in 2020. Meanwhile, Standard and Poor's predicts Indonesia's economic growth will slow to $1.8 \%$ this year. (Suryahadi, 2020). The impact on the economic sector is caused as a domino effect from the weakening of other sectors, which causes a decline and even losses for investors. In addition, the Covid-19 pandemic threatens all sectors that depend on mobility and social interaction and require gathering large people.

The impact of the pandemic on the global economy and finances raises complex problems, where economic weakness will affect all economic actors, governments, corporations, MSMEs, and the financial sector. First, from the government side, a decrease in state revenues, both tax and nontax, an increase in state spending for economic recovery, and an increase in the budget deficit can increase government debt for delaying strategic projects, including infrastructure. Second, from the corporate side, the decline in production and marketing in various business fields and disruption of business activities will result in low company performance, low income, termination of employment, and potential for bankruptcy. Third, in the case of Micro, Small, and Medium Enterprises (MSMEs), a weak economy will lead to a decline in production and sales and even threaten business continuity. Fourth, debt that MSME entrepreneurs must bear will cause an increase in Non-Performing Loans (NPL) and Non-Performing Financing (NPF), so that the real sector at the regional and national levels will be disrupted. Fourth, from the Financial Sector, a decline in business activity will disrupt the banking and financing sectors as long as it can cause liquidity and bankruptcy. The possibility of increasing NPL and NPF also causes problems in the financial sector. In terms of the Financial Sector, a decline in activity in the business sector will disrupt the banking and financing sectors as long as it can cause liquidity and bankruptcy. The possibility of increasing NPL and NPF also causes problems in the financial sector. In terms of the Financial Sector, a decline in activity in the business sector will disrupt the banking and financing sectors as long as it can cause liquidity and bankruptcy. The possibility of increasing NPL and NPF also causes problems in the financial sector.

In Indonesia, the MSME sector has a strategic role in the economy by absorbing labor, indirectly reducing unemployment and poverty levels. For the national economy, MSMEs are important because they can increase GDP up to $59.08 \%$ or equivalent to IDR 4,869.57 trillion with a growth rate of 
6.4\% per year. (BI and LPPI, 2015:17). Suhaili and Sugiharsono (2019: 312) noted that between 2012-2017, MSMEs contributed greatly to Indonesia's GDP with an average estimate of $59.74 \%$ or equivalent to IDR $5,928,934.98$ billion.

Based on a Bloomberg survey (Green, 2020), many MSMEs have difficulty maintaining their business continuity, even adjusting their operational needs for approximately one or two months, such as rent payments, loans, and employee salaries. Around $30 \%$ of the business groups experienced liquidity problems and failed to maintain their business after one or two months. Moreover, only $9 \%$ of all MSME groups survived for six months during the pandemic. Meanwhile, in Indonesia, the Deputy Chairperson of the Indonesian Chamber of Commerce and Industry for Good Corporate Governance (GCG) and Corporate Social Responsibility (CSR) stated that from February to April 2020, MSME sales decreased by 70\%. (CNBC Indonesia, 2020).

The impact of the pandemic on the economy has been the subject of expert study for several years. Brown et al. (2010: 1345) in their work entitled "The Possible Macroeconomic Impact On The UK of an Influenza Pandemic," examines the impact of the influenza pandemic on the macroeconomics of the United Kingdom. Brown applied the UK 'COMPACT' macroeconomic model to epidemiological data on several previous influenza pandemics in the UK, considering the possible more severe risks. The analysis shows the economic impact of the influenza pandemic in England in 1957 or 1968 has caused a decline in GDP of $3.35 \%$ in the first three months and $0.58 \%$ in one year. However, an analysis that looked at possible more severe impact scenarios (More than 1\% of the population died) showed that the UK experienced a $21 \%$ decline in GDP in the first three months and $4.5 \%$ in one year. The calculation of this impact is related to the government's policy of imposing temporary school closures. The economic impact is expected to be even greater if the policy is not implemented so that the number of infected patients increases sharply every week.

The impact of the Covid-19 pandemic on the economy is not expected to be as difficult and extensive as the global crisis from 2008 to 2009 (Baldwin \& Tomiura, 2020: 67). Warwick McKibbin and Roshen Fernando (2020: 6) examine the impact of Covid-19 on macroeconomic and financial market outcomes in the DSGE/CGE general equilibrium global model using seven different scenarios regarding the possible evolution of this virus. The Covid-19 pandemic, if predicted to end soon like the Hong Kong Flu, is expected to lower global GDP by around US\$2.4 trillion in 2020. If the pandemic is more severe as the Spanish $\mathrm{flu}$, it is expected to lower global GDP-more than US\$9 trillion.

The uncertainty of the evolution of the disease and the economic impact caused by Covid-19 makes it difficult for policymakers to formulate appropriate macroeconomic policy responses. Economic shocks are related to market demand issues and are multisectoral crises that require monetary, fiscal, political, and health policy responses. Therefore, various policy responses are needed, both short and long-term. According to Kibbin and Fernando (2020: 25), quarantine policies and restrictions on largescale social interactions are the most effective 
measures. The practice of clean and healthy living goes hand in hand with cleaning public facilities on a large scale even though it requires quite a low cost

but is considered very effective in reducing the rate of virus transmission. This will reduce social and economic costs. In the short term, central banks and finance ministries need to ensure that the economy continues despite the ongoing disease outbreak. The government plays an essential role in overcoming financial pressure, while the Central Bank can provide interest rate cuts.

The long-term response is important as experts have warned that animal-borne or zoonotic diseases will continue to threaten life with the potential for major disruption to the world economy. However, many governments have been reluctant to invest in the health sector recently, especially in less developed countries. Therefore, global cooperation, particularly in public health and economic development, is essential. The study of McKibbin \& Fernando (2020: 26) shows that the economic burden of the pandemic can be avoided by investing in global cooperation in public health in all countries.

The Covid-19 pandemic has affected various key economic sectors, especially the travel, tourism, and retail sectors, and other services. The sector that is most vulnerable to the coronavirus is MSMEs, given the limited resources to deal with the pandemic. The effect of the Covid-19 pandemic on the financial system will depend on i) the extent to which the virus will spread around the world and its effect on economic activity, ii) fiscal and monetary policies facing the crisis, and iii) regulatory measures to be avoided possible fragility of the banking system (Asean, 2020).

The International Labor Organization estimates that 5 to 25 million jobs in the world will be lost due to this pandemic (United Nations, 2020). Bouey (2020:7) revealed a survey conducted by researchers from Tsinghua University of 995 SMEs in February showed that 30 percent of SMEs experienced a decline in income of more than $50 \%$, while another $28 \%$ reported a decline of 20 to $50 \%$. More than a third of SMEs said they were only able to survive for a month with their cash flow, 33\% were able to survive for two months, and less than $10 \%$ could run their business for more than six months. The largest SME operational financing costs, $62.8 \%$, were paid for salaries, labor insurance, and security costs. Rental and borrowing costs occupy the second and third costs.

Based on interviews that the author conducted with 100 MSME entrepreneurs in the Semarang, Demak, and Kendal areas, they experienced a decline in sales due to the Covid-19 pandemic. About 86\% of MSMEs experienced a drastic decline in sales. Around 63 MSMEs or $63 \%$ complained of difficulties accessing raw materials, while $84 \%$ stated that product distribution channels were hampered. It was recorded that 70 MSMEs, equivalent to $70 \%$, complained about funding problems. Around 70\% of MSME owners revealed that their production was constrained by the Covid-19 outbreak, while $30 \%$ of MSMEs had difficulty paying rent.

Taking into account the findings of the data above, the problems faced by MSMEs require various rescue and mitigation efforts and policies in the economic, social, and political 
fields from the government and the Financial System Stability Committee (KSSK). The policy initiated by the government still requires additional efforts to save MSMEs affected by the Covid-19 pandemic. Based on the description of the background above, This study analyzes efforts in rescuing MSMEs to maintain the stability of the national financial system affected by the Covid-19 pandemic.

\section{Literature Review}

According to Purwanti (2016: 16), MSMEs are generally defined based on quantitative criteria, such as the number of workers, total assets, and annual income. Bank Indonesia and LPPI (2015: 12) explain that MSMEs are divided into three types based on the number of resources, first, Micro Business with a maximum of 10 employees; second, a small business with 30 employees; and third, Medium Enterprises with 300 employees. In addition, there are different characteristics of each type.

MSMEs are economic growth and innovation engines that control $90 \%$ of businesses and provide $50 \%$ of jobs in the world. As a result, the MSME sector contributes significantly to world economic growth as a source of Gross Domestic Product (GDP) of around 70\% of the volume of goods and services (APEC, 2020: 10).

Anggraeni (2013: 1287) reveals that MSMEs are potential businesses for economic development in Indonesia, so they need to be maximized and explored to improve the community's economic development. However, MSMEs are different from other businesses in the aspect of commodities produced, including the quality and raw materials of products that have not been standardized and designs and types that are still limited (BI and LPPI, 2015: 15).

According to the international standard classification of economic sector activities, MSMEs are categorized into nine business fields. They are 1) agriculture, animal husbandry, forestry, and fisheries by $48.85 \%$ in Indonesia; 2) mining and quarrying about $0.53 \%$; 3) process industry by $6.41 \%$; 4) electricity, gas, and clean water by $0.03 \%$; 5 ) construction $1.57 \%$; 6) trade, hotels, and restaurants around $28.83 \%$; 7) transportation and communication $6.88 \%$; 8) finance, leasing, and business services by $2.37 \%$; and 9) private services by $4.52 \%$ (BI and LPPI, 2015: 9).

In this pandemic period, MSMEs receive special attention from every country because they are expected to survive the economic turmoil so that the financial system is expected to remain stable. Financial system stability is a stable financial system that can allocate sources of funds and face economic shocks to prevent disruption of the real sector and the financial system (BI, 2007: 20).

Delilah (2016: 415) said that the European Central Bank describes the financial system's stability as a condition where the financial system can overcome shocks and minimize obstacles in the financial intermediation process. Likewise, Sari et al. (2015) state that financial system stability is the financial system's resilience to economic shocks, so that the intermediation function, payment system, and risk distribution continue to run well.

The financial system must be stable and efficient to carry out its intermediation function optimally by channeling funds from 
excess parties (surplus) to parties experiencing deficits (Endri, 2009: 120). Meanwhile, the stability of the financial system in Indonesia experienced a slowdown starting in early March 2020. This condition was only influenced by the coronavirus outbreak, which caused the economic sector in Indonesia to experience a decline in income. As a result, several sectors were closed to minimize the spread of Covid-19. Therefore, the government needs to address this issue to maintain economic stability and sustainability immediately.

\section{The Method, data, and analysis}

This study examines ways to save MSMEs affected by the Covid-19 pandemic to maintain the stability of the national financial system by using a qualitative descriptive literature study. Qualitative research is a method designed to uncover temporary life issues that will develop in the field-research data obtained from literature study and interviews.

The literature study method is a series of activities related to collecting library data, reading, taking notes, and processing research materials (Kartiningrum, 2015). Data are collected from various sources such as textbooks, journals, articles, literature reviews, and statistical data discussed in this field. According to Bungin (2011), a Literature study is one of the data collection methods used in social research to explore data.

Interviews were conducted with 100 MSMEs spread across Semarang, Demak, and Kendal regencies carried out between September and December 2020. The interview is a dialogue carried out by two parties, namely the interviewer and the interviewee, with a specific purpose for writing. (Moleong, 2017: 186). This study uses semi-structured interviews, which are more flexible than structured interviews (Sugiyono, 2018). The purpose of this interview was to find more open problems, where the interviewees were asked about the problems faced by their MSMEs due to the Covid-19 pandemic. Data analysis begins with relevant research findings and reviews previous research to assess the problem. Important and relevant parts of the research topic are recorded, including the data source.

\section{Result and Discussion}

The empowerment of MSMEs is a concrete action to move the national economy with its contribution and role in absorbing more workers than other business entities. The advantages of MSMEs in reducing unemployment and poverty have proven to be very important as (1) major players in economic activity, (2) largest job providers, (3) essential players in local economic development and community empowerment, (4) creators of new markets and sources of employment. Innovation, and (5) its contribution to the stability of the state financial system.

As quoted by Singgih (2007), Ishak states that as a support for the national economy, MSMEs are not a business sector that is free from problems. For example, as we know, MSMEs are one of the sectors most affected by the Corona Virus (Covid-19) outbreak. Based on interviews with 100 MSMEs in 
Semarang City, Demak District, and Kendal District, the problems faced by MSMEs during the Covid-19 pandemic were declining sales, difficulty in obtaining raw materials, business capital, and payment of rent, as well as production and distribution disruptions.

Since the Corona outbreak in Indonesia, public purchases have decreased. This is what causes the decline in MSME sales income. A total of 86 MSMEs, or equivalent to $86 \%$, stated that their sales had decreased drastically since the outbreak of the Corona Virus. The problem of declining purchases was also experienced by people in China and the United States. In a survey conducted by a Beijing financial firm, nearly $65 \%$ of respondents plan to "bridle" their shopping habits after the Covid-19 pandemic (Rose, 2020). In the United States, people drastically change their spending by reducing secondary and tertiary needs and prioritizing basic needs (Baker et al., 2020).

In addition to the decline in income, MSMEs also admitted that they had difficulty getting raw materials as the basic ingredients of the production process due to social distancing policies or appeals. Based on the data we have collected, about $63 \mathrm{MSMEs}$ or the equivalent of $63 \%$, complain about the difficulty of getting raw materials. A total of 84 MSMEs, equivalent to $84 \%$, stated that the Covid-19 pandemic disrupted the distribution channels of their products, primarily when social distancing and physical distancing had been implemented.

It was recorded that 70 MSMEs or the equivalent of $70 \%$, complained of having capital constraints. At the same time, 10 MSMEs plan to close their businesses because they can no longer find business capital. 70\% of MSME owners said that the Covid-19 outbreak hampered their production. Around $30 \%$ of MSMEs are in trouble because the rent for their place of business and several other bills are unaffordable. Even if business owners give them relief by deferring their billing lease for two or three months, MSMEs may still face difficulties paying all the bills. This type of difficulty can force MSMEs to permanently close their businesses because it is impossible to predict how long the impact of the pandemic will last.

The complaint shows that the Corona outbreak has indeed greatly affected the MSME business. The Board of Innovation (2020) even assesses the impact experienced by MSMEs is very high. Therefore, MSME owners must be prepared to anticipate so that their business remains productive and does not go out of business.

The impact of the Covid-19 pandemic is also huge, found in the tourism sector, which provides travel and hospitality services because this business requires the highest mobility (Gopalakrishnan et al., 2020). At the same time, various industrial sectors have a reasonably high impact, such as the sports, music, and automotive industries. On the other hand, the impact on the retail industry sector is moderate (Board of Innovation, 2020). Only the pharmaceutical sector is expected to experience a low impact.

Even though the impact is tremendous, MSMEs are the most crucial sector to be saved to maintain the national economy's stability. MSMEs are the most prominent actors in the Indonesian economy and have proven to be a safety valve for the national economy in times of crisis and a driver of economic growth afterward. As the largest provider of employment in Indonesia, MSMEs are significant to be safe because they 
have a wide-reaching multiplier effect. The more people are free from unemployment, the better the economy will be. Moreover, MSMEs are spread across all regions in Indonesia following the distribution of the population. In addition, MSMEs are proven to significantly contribute to GDP (Board Of Innovation, 2020). Each state is asked to provide support for MSMEs. Therefore, saving MSMEs is very strategic from an economic, social and political perspective.

In addition to the uncertainty of the impact caused by Covid-19, especially in other sectors, MSMEs adapt more quickly to adverse conditions and survive various economic conditions. This is also evidenced by China, which still relies heavily on MSMEs to boost its economic growth. The prospect of national economic growth is strongly influenced by the dynamics of the global economy. However, the COVID-19 outbreak that disrupts investor confidence, financial markets, the tourism/travel sector, and the supply chain could be a turning point for Indonesia to strengthen the domestic economy through empowering MSMEs, starting from the production process, supply of raw materials and basic needs. need to produce internationally competitive products.

Many factors can help MSMEs survive the crisis and recover quickly after the Covid-19 pandemic, including government stimulus, consumer confidence, and a decrease in the number of Covid-19 infection cases. Many countries have taken steps to save their economies during the pandemic, including providing stimulus to protect MSMEs.

The Chinese government provides leniency for MSMEs who have difficulty paying loans in the form of leniency in loan repayments and tolerance for the ratio of bad loans. In February, China's State Council approved a loan of US $\$ 114.2$ billion to MSMEs (Bouey, 2020:10). The State Council also instructed large state-owned banks to increase lending to MSMEs by at least 30 percent in the first half of 2020. The People's Bank of China provided support by expanding re-lending facilities and discounted rates to support SMEs by US\$43. billion. Protection is also provided through cutting the cash reserve limit by 100 basis points to joint-stock banks that support private SMEs, as well as an extension of the bank's credit policy for MSMEs by US $\$ 49$ billion. Meanwhile, China's three state-run development banks were asked to provide loans of US\$ 49.7 billion to MSMEs (Bouey, 2020: 8). Private commercial banks are also supported to postpone loan interest claims to MSMEs experiencing cash flow difficulties until the end of June and temporarily delay credit payments. The Chinese government also encourages local business actors to provide fiscal support so that MSMEs can survive. For example, Beijing announced a series of measures to help MSMEs, including releasing rent bills for two months and reducing taxes and contributions to the national social security fund.

The Australian government adopted a different strategy: hibernation by providing tax breaks for around 690 thousand MSMEs with a turnover of under AUD 50 million and 30 thousand non-profit institutions. Funds disbursed by Australia for this assistance amounted to AUD 20 thousand (approximately IDR 195 million) to AUD 100 thousand (approximately IDR 973 million). The first automatic credit is up to AUD 50 million for activity reports from 
March to June 2020, while the second automatic credit is the same amount from July to September 2020 (KPMG, 2020).

The support of ASEAN countries to MSMEs is not much different, namely in the form of lending, tax subsidies, and wages. Malaysia with 40 percent contribution of SMEs to the country's economy provides double the stimulus, each amounting to US \$ 1 billion to help SMEs. This stimulus is provided through the Special Assistance Fund, All Economic Sectors (AES) program facilities and microcredit (Madinah, 2020). A special grant of US $\$ 4,500$ to US $\$ 226,000$ is distributed to eligible SMEs for 5.5 years with a maximum interest rate of 3.75 per year and a moratorium on payments for 6 months. The AES program with an allocation of US\$ 229 million facilitates the financing of SMEs for a period of five years at an interest rate of $7 \%$ per annum. Meanwhile, funding of US\$ 114 million was provided through a micro-credit scheme that allows small businesses to obtain loans of up to US $\$ 17,000$ at an interest rate of $2 \%$. In addition, the Central Bank of Malaysia helps MSMEs through a credit scheme of more than IDR 17 trillion.

Meanwhile, Singapore uses state reserves of Rp 548 trillion to support the MSME and household sectors. Support from the Monetary Authority of Singapore (Monetary Authority of Singapore, 2020) for MSMEs is implemented by providing sustainable access to bank loans and insurance protection and ensuring the interbank funding market remains liquid and functioning properly. Several banks and financial companies in Singapore have committed to help ease the burden on MSMEs by easing loan principal payments for a certain period of time during the pandemic based on an assessment of the security quality of SMEs until December 31, 2020. SMEs with a good reputation in credit payments can also extend the loan term for certain period of time or adjust the bill payment schedule. To support these efforts, the Singapore government also provides funding facilities for banks and financial companies that provide working capital loans and temporary loan programs to SMEs. This program is expected to have the potential to reduce MSME loan interest rates. The relief provided to SMEs also applies to the payment of insurance premiums, considering that all companies in Singapore including SMEs are required to have general insurance to protect their business and property from risks. SMEs can pay a smaller amount of insurance premiums and get protection throughout the payment period.

In addition to the protection schemes provided by the government to MSMEs, MSME actors also need to prepare internal steps to overcome these problems. Some alternative solutions are changing the way of marketing and selling online, switching product/service lines, changing production capital budget, ensuring product cleanliness and halalness, issuing shopping vouchers or gift cards, accelerating asset sales, and considering employee reductions.

The use of digital media will be the best solution to help MSMEs continue to run. Large-scale social restrictions and crowd avoidance have resulted in an extreme increase in the use of the internet, and social media, including the demand for takeout and online shopping. (Donthu \& Gustafsson, 2020: 285; Taufik \& Ayuningtyas, 2020: 28). Digital technology and social media also help manage resources effectively, make communication faster within MSMEs and 
with customers and partners, increase productivity, and lower transaction costs because advertising is cheaper and spreads faster. (Gerguri-Rashiti et al, 2017; Saleh, 2020; Okundaye et al, 2019).

There are several e-commerce sites or applications that can be used by MSMEs such as shopee, tokopedia, OLX, lazada, gojek, grab etc. In this case, the government can provide facilities in the form of digitization through a special marketplace for local MSMEs. A well-developed digital economy will play a greater role in supporting economic activity and reducing the effects of recession (Ozili, 2020). This strategy can help MSMEs reach consumers with limited mobility. Online marketing and sales flow can be seen in the following scheme:

Figure 1. MSME Online Marketing and Sales Scheme

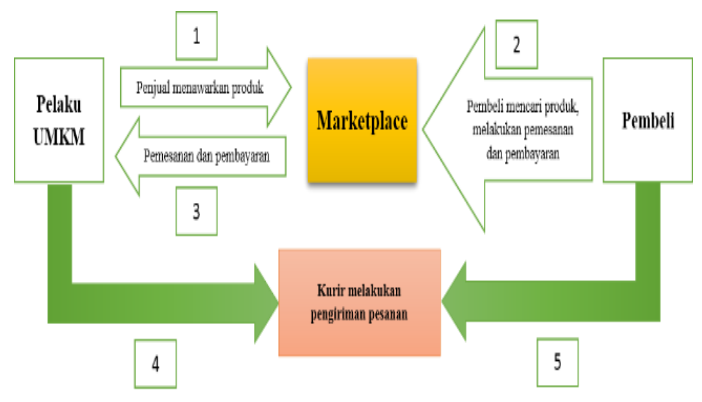

Source: (Lesmana, 2016), 2021 Model Year Development

The online marketing and sales strategy starts with MSMEs such as sellers of vegetables, basic commodities, food, fruits, etc. Register yourself in a marketplace system or application. The buyer searches for the required product in the market and places an order to make payment. The marketplace system then issues notifications for orders and payments from buyers to MSMEs. Couriers consisting of pedicab drivers, public transportation, motorcycle taxis, or delivery service providers deliver the purchased goods to the buyer.

Digital media has become very important for MSMEs in maintaining existing customer relationships and communicating with them to build trust (Liguori \& Pittz, 2020: 108). Reaching out to them will help identify market demands that will be useful for improving and developing their products and services. According to Pelham (Pelham, 2000), market-oriented MSMEs are more likely to excel, especially if they follow a growth or differentiation strategy. Staying connected to the entrepreneurial community is also important because it stimulates higher levels of creativity and innovation, and can be a source of recognition (Liguori et al., 2019). In addition, digital media helps in investigating current and future trends (Eggers et al., 2017: 274).

During the Covid-19 pandemic, MSMEs must be more adaptive and innovative to the situation and conditions. The Covid-19 pandemic has certainly brought changes to consumer behavior and consumption. This situation encourages the maintenance of supplies of primary needs such as medical, hygiene, food, and agricultural products in accordance with the needs of the community. Therefore, MSMEs need to shift their line of goods or services to other lines that are more needed during the pandemic. Competitive advantage through market orientation and product innovation will determine the sustainability of MSMEs (Alwi \& Handayani, 
2018). Several internet-based businesses are increasingly in demand, such as those related to food delivery, online shopping, health care and medicine, solutions for remote work, online education, and online entertainment. (Donthu \& Gustafsson, 2020: 285; Sugiyanto et al., 2020: 236).

Jaworski et al. (2000) note that markets are dynamic and can move quickly. However, business changes must be based on estimates of ease of access to suppliers, ability to obtain raw materials, materials or logistics and potential customers to identify risks and opportunities. MSMEs must use a cost and benefit analysis that links cross-functional risk mitigation planning with the company's strategy (Fitriasari, 2020: 59).

To maintain business continuity, MSME actors are required to reallocate their business capital. MSMEs must prepare cash flows by taking into account various scenarios, namely decreased revenues, new operating models, reduced operating costs, and bad loans.

The Covid-19 outbreak has brought people to prioritize their health. People are starting to realize the importance of maintaining health and paying attention to hygiene consumption to maintain immunity. One of the people's purchasing preferences during the pandemic is cleanliness, hygiene and most importantly, the clarity of product ingredients. (Hardilawati, 2020). Products with halal labels are considered to be able to guarantee these things. In addition to product hygiene, MSMEs must ensure that workers involved in the supply chain are free from Covid-19 infections. This is very important not only to protect workers and consumers, but also to provide support to frontline medical personnel and other infected and vulnerable groups. The implementation of the health protocol is also expected to boost the current sales of MSMEs.

MSMEs engaged in textiles, home furnishings, souvenirs, accessories, lodging, restaurants, and basic food stores can carry out a strategy by offering vouchers or gift cards to consumers that can be used after the pandemic ends. This effort can help MSMEs maintain cash flow for business continuity.

Cash flow preparation during the pandemic can force MSME owners to sell non-essential business assets if they have minimum savings or fail to secure loans. Therefore, it is important for MSMEs to have non-essential business assets (eg land, vehicles, and gold) to deal with these unexpected conditions. MSME owners should consider whether assets can be sold quickly in epidemic conditions to maintain business continuity.

MSME owners also need to prepare for the worst-case scenario to ensure that the business can continue to run. The final alternative is to consider a combination of reduced hours worked, voluntary wage cuts, paid leave, unpaid voluntary leave, suspension of employment and termination of employment. Therefore, MSME owners must identify key personnel for their operational activities.

In addition to these efforts, active support from state and local governments is needed to help MSMEs implement the above strategies. The government can channel MSME products online by creating a special marketplace for local MSMEs. Currently there is $\mathrm{PaDi}$ (Digital Market) as a marketplace for goods and services that can be purchased by state-owned companies. In difficult times like now, the government also needs to ensure price stability, availability, and accessibility of basic necessities. This 
action will help MSMEs to produce goods and services. Moreover, the government needs to buy MSME products to be promoted.

The central and local governments should also consider other schemes to support MSMEs by collaborating with business actors or private institutions, ranging from loans for a certain period of time with reduced interest rates, cash grants, reduced business premises rental fees, or empowerment of MSMEs. through capacity building and digital training. Digital literacy for MSMEs is one of the social and digital strategies to respond to changes that occur in the market in the long term. (Amri, 2020: 129; Pakpahan, 2020: 63).

Since April 2020 the government has collaborated with the private sector to run digital training programs for MSMEs, for example redesigning websites or

Using online platforms and social media as a means of communication with repeat customers. There are several programs such as the e-learning program, namely edukukm.id initiated by the Ministry of Cooperatives and SMEs, the Tourism UKM Online Training Program by the Ministry of Tourism and Creative Economy, and most recently an online class planned by the Ministry of Communication and Information Technology team. with e-commerce.

Most importantly, the Central Government needs to prepare a mechanism for MSMEs to support pandemic control. Furthermore, local governments need to inform and monitor MSMEs whether they have met the Covid-19 prevention requirements, monitor the implementation of disease prevention methods, and help them make plans for emergencies.

This policy can be adopted from the efforts of the Chinese Government in applying the principle of balance between support for MSMEs and controlling the pandemic after the lockdown. Bouey (2020: 8) outlines the main considerations of the Regional Government in granting permits to reopen MSMEs. First, the readiness of SMEs to prevent the spread of Covid-19. Second, priority is given to businesses that are on the top list of local governments, for example those that have an impact on urban development, daily needs and make a significant contribution to the regional economy. Third, MSMEs that are able to produce PPE and medical aids are prioritized. Based on the analysis and strategic scenarios above, it is expected to increase MSME resilience in facing economic conditions. MSMEs that survive greatly impact the stability of the national financial system.

\section{Conclusion}

Based on the studies that have been carried out, MSMEs are a very crucial business sector and are able to adapt quickly in unexpected crisis conditions. The researcher proposes seven MSME defensive scenarios that can be implemented by business actors and need positive support from the government, financial and banking institutions and the community. First, the transformation of the way of marketing and selling online. Second, shifting product/service lines. Third, the reallocation of production capital. Fourth, guarantee product hygiene and halal quality. Fifth, giving shopping vouchers or gift cards. Sixth, acceleration of asset sales. Seventh, the 
reduction of the workforce. The seven scenarios above can be an alternative solution for MSMEs to survive in unstable economic conditions due to the Covid-19 pandemic. However, the results of this study have limitations for MSMEs in areas that are still limited by internet networks so that they have difficulty implementing digital-based marketing strategies. The higher the number of MSMEs that are able to survive and develop their businesses, the greater their contribution as an economic and social safety net. MSMEs that survive can reduce unemployment in Indonesia. Good MSME resilience keeps GDP from extreme decline. Thus, MSMEs can immediately save the stability of the national financial system.

\section{Suggestion}

For the continuation of this research, digital implementation is still needed. The government's concern for health is also important to raise so that it does not have a long-lasting impact on the economy due to the distrust of the world community. This study is still limited to the MSME business, so it needs to be developed and applied to other business sectors

\section{References}

Alwi, T., \& Handayani, E. (2018). Keunggulan Bersaing UKM yang Dipengaruhi Oleh Orientasi Pasar dan Inovasi Produk. Jurnal Pengembangan Wiraswasta, 20(3), 193-202. https://doi.org/10.33370/jpw.v20i3.25 6

Amri, A. (2020). Dampak Covid-19 Terhadap UMKM di Indonesia. Jurnal Brand, 2(1),
$123-130$.

Anggraeni, F. D., \& Al., E. (2013). Pengembangan Usaha Mikro, Kecil Dan Menengah (UMKM) Melalui Fasilitasi Pihak Eksternal Dan Potensi Internal (Studi Kasus Pada Kelompok Usaha "Emping Jagung" Di Kelurahan Pandanwangi Kecamatan Blimbing Kota Malang). Jurnal Administrasi Publik, 1(6), 1286-1295.

APEC. (2020). Intellectual Property Commercialization for SMEs. Intellectual Property Commercialization for SMEs, 124.

Asean, P. B. (2020). Economic Impact of Covid-19 Outbreak on ASEAN. Association of Southeast Asian Nations (ASEAN).

Baker, S. R., Farrokhnia, R. A., Meyer, S., Pagel, M., \& Yannelis, C. (2020). How Does Household Spending Respond To an Epidemic? Consumption. In NBER Working Paper No. 26866.

Baldwin, R., \& Tomiura, E. (2020). Thinking ahead about the trade impact of COVID-19. In CEPR Press.

Bank Indonesia. (2007). Booklet Stabilitas Sistem Keuangan. Bank Indonesia.

Bank Indonesia dan LPPI. (2015). Profil Bisnis Usaha Mikro, Kecil dan Menengah (UMKM). Bank Indonesia Dan LPPI.

Board of Innovation. (2020). Covid-19 Industry Impact. Board of Innovation.

Bouey, J. (2020). Assessment of COVID-19's Impact on Small and Medium-Sized Enterprises: Implications from China. In Assessment of COVID-19's Impact on 
Small and Medium-Sized Enterprises: Implications from China. https://doi.org/10.7249/ct524

Bungin, B. (2011). Penelitian Kualitatif: Komunikasi, Ekonomi, Kebijakan Publik, Dan Ilmu Sosial Lainnya. In Kencana.

CNBC Indonesia. (2020). Kadin: Penjualan UMKM di Masa Covid-19 Turun Hingga 70\%. CNBC Indonesia.

Dienillah, A. A., \& Anggraeni, L. (2016). Dampak Inklusi Keuangan Terhadap Stabilitas Sistem Keuangan Di Asia. Buletin Ekonomi Moneter Dan Perbankan. https://doi.org/10.21098/bemp.v18i4. 574

Donthu, N., \& Gustafsson, A. (2020). Effects of COVID-19 on business and research. In Journal of Business Research. https://doi.org/10.1016/j.jbusres.2020. 06.008

Eggers, F., Hatak, I., Kraus, S., \& Niemand, T. (2017). Technologies That Support Marketing and Market Development in SMEs-Evidence from Social Networks. Journal of Small Business Management. https://doi.org/10.1111/jsbm.12313

Endri. (2009). Penguatan Stabilitas Sistem Keuangan Melalui Peningkatan Fungsi Intermediasi Dan Efisiensi Bank Pembangunan Daerah (BPD). Jurnal Keuangan Dan Perbankan.

Fitriasari, F. (2020). How do Small and Medium Enterprise (SME) survive the COVID-19 outbreak? Jurnal Inovasi Ekonomi.

https://doi.org/10.22219/jiko.v5i3.118 38
Gërguri-Rashiti, S., Ramadani, V., Abazi-Alili, H., Dana, L. P., \& Ratten, V. (2017). ICT, Innovation and Firm Performance: The Transition Economies Context. Thunderbird International Business Review. https://doi.org/10.1002/tie.21772

Gopalakrishnan, B., Peters, R., \& Vanzetti, D. (2020). Covid-19 and Tourism. Economic Consequences.

Green, J. (2020). Covid-19 Is Becoming the Disease That Divides Us: By Race, Class and Age. Bloomberg.

Hardilawati, W. laura. (2020). Strategi Bertahan UMKM di Tengah Pandemi Covid-19. Jurnal Akuntansi Dan Ekonomika. https://doi.org/10.37859/jae.v10i1.193 4

Jaworski, B., Kohli, A. K., \& Sahay, A. (2000). Market-driven versus driving markets. Journal of the Academy of Marketing

Science. https://doi.org/10.1177/00920703002 81005

Kartiningrum, E. D. (2015). Panduan Penyusunan Studi Literatur. Lembaga Penelitian Dan Pengabdian Masyarakat Politeknik Kesehatan Majapahit, Mojokerto.

Keogh-Brown, M. R., Wren-Lewis, S., Edmunds, W. J., Beutels, P., \& Smith, R. D. (2010). The possible macroeconomic impact on the UK of an influenza pandemic. Health Economics. https://doi.org/10.1002/hec.1554

KPMG. (2020). Covid-19 SME Hibernation Guide: Restructuring Service. 
Liguori, E., Bendickson, J., Solomon, S., \& McDowell, W. C. (2019). Development of a multi-dimensional measure for assessing entrepreneurial ecosystems. Entrepreneurship and Regional Development.

https://doi.org/10.1080/08985626.201 8.1537144

Liguori, E. W., \& Pittz, T. G. (2020). Strategies for small business: Surviving and thriving in the era of COVID-19. Journal of the International Council for Small Business. https://doi.org/10.1080/26437015.202 0.1779538

McKibbin, W. J., \& Fernando, R. (2020). The Global Macroeconomic Impacts of COVID-19: Seven Scenarios. SSRN Electronic Journal, 116-156. https://doi.org/10.2139/ssrn.3547729

Medina, A. F. (2020). Malaysia Issues Second Stimulus Package to Combat COVID19: Salient Features. In Asean Briefing.

Moleong, L. J. (2017). Metodologi Penelitian Kualitatif (Edisi Revisi). In PT. Remaja Rosda Karya.

Monetary Authority of Singapore. (2020). MAS and Financial Industry to Support Individuals and SMEs Affected by the COVID-19 Pandemic. Monetary Authority of Singapore.

Okundaye, K., Fan, S. K., \& Dwyer, R. J. (2019). Impact of information and communication technology in Nigerian small-to medium-sized enterprises. Journal of Economics, Finance and Administrative Science. https://doi.org/10.1108/JEFAS-082018-0086
Ozili, P. K. (2020). COVID-19 Pandemic and Economic Crisis: The Nigerian Experience and Structural Causes. SSRN Electronic Journal. https://doi.org/10.2139/ssrn.3567419

Pakpahan, A. K. (2020). COVID-19 dan Implikasi Bagi Usaha Mikro, Kecil, dan Menengah. Jurnal Ilmiah Hubungan Internasional, Special edition, 59-64. https://doi.org/10.26593/jihi.v0i0.387 0.59-64

Pelham, A. M. (2000). Market orientation and other potential influences on performance in small and medium-sized manufacturing firms. Journal of Small Business Management.

Purwanti, I. (2016). Strategi Pengembangan Startup UMKM Berbasis Syariah Melalui Penciptaan Kompetensi Inti. In F. Pratikto, Heri; Winarno, Agung; Sutrisno; Siswoyo, Bambang Agung; Hermawan, Agus; Isnani, Gatot; Arief, Muhammad; Mukhlis, Imam; Rahmawati (Ed.), Prosiding Seminar Nasional dan Call for Papers Ekonomi Syariah: Ekonomi Syariah Dalam Pemberdayaan Sektor Riil di Indonesia (pp. 13-24). CV AMPUH MULTI REJEKI.

Putu Dody Lesmana, D. R. H. (2016). Pengembangan dan Promosi E-Comerce UKM Jaya Makmur Untuk memperluas Jaringan Pemasaran Produk Kerajinan Bambu. Seminar Hasil Penelitian BOPTN.

Rose, J. (2020). COVID-19 Crash: How China's Economy May Offer a Glimpse of the Future. Visual Capitalist.

Saleh, Y. (2020). ICT, social media and COVID-19: evidence from informal home-based business community in 
Kuwait City. Journal of Enterprising Communities.

https://doi.org/10.1108/JEC-07-2020-

0131

Sari, D. I. (2015). Analisis terhadap Peranan dan Strategi Bank Indonesia serta Pemerintah dalam Menjaga Stabilitas Sistem Keuangan di Indonesia. MoneterJurnal Akuntansi Dan Keuangan.

Singgih, M. N. (2007). Strategi Penguatan Usaha Mikro Kecil Menengah (UMKM) Sebagai Refleksi Pembelajaran Krisis Ekonomi Indonesia. Ekonomi Modernisasi.

Sugiyanto, S., Suma, D., \& Prayeki, P. (2020). POSITIVE VALUE OF COVID 19 PANDEMIC FOR MSMEs: A CASE STUDY IN YOGYAKARTA. International Journal of Economics, Business and Accounting Research (IJEBAR). https://doi.org/10.29040/ijebar.v4i03. 1121

Sugiyono. (2018). Metode Penelitian Kuantitatif,Kualitatif dan R\&D. In Ke26.

Suhaili, M., \& Sugiharsono, S. (2019). Role of MSME in Absorbing Labor and
Contribution to GDP. Economics

Development Analysis Journal. https://doi.org/10.15294/edaj.v8i3.352 29

Suryahadi, A. (2020). SEP pangkas outlook Indonesia, bagaimana dampaknya ke pergerakan IHSG? Kontan.

Taufik, \& Ayuningtyas, E. A. (2020). Dampak Pandemi COVID-19 Terhadap Bisnis dan Eksistensi Platform Online (The Impact of Covid-19 Pandemic on Business and Online Platform Existance). Jurnal Pengembangan Wiraswasta.

UN Department of Global Communications. (2020). Press Release: COVID-19 Likely to Shrink Global GDP by Almost One Per Cent in 2020: Bold and Urgent Policy Measures Needed to Protect the Most Vulnerable and Promote Sustainability.

United Nations. (2020). United Nations Secretary-General launches plan to address the potentially devastating socioeconomic impacts of COVID-19: Establishes global fund to support lowand middle-income countries. In United Nations Press Release 31 March 2020. 